\title{
Aktivitas antimikroba dan antioksidan ekstrak tepung daun dan buah mengkudu (Morinda citrifolia)
}

\section{Antimicrobial and antioxidant activity of extract eeave and noni Fruit (Morinda citrifolia) powder}

\author{
David Kurniawan* \\ Universitas Kahuripan Kediri \\ Jl. Soekarno-Hatta No. 1, Pelem, Pare, Kediri, Jawa Timur
}

Submitted: 10 January 2018, Accepted: 9 May 2018

\begin{abstract}
ABSTRAK: Tanaman mengkudu merupakan jenis tanaman obat yang mempunyai senyawa bioaktif antimikroba dan antioksidan yang berpotensi digunakan sebagai aditif pakan pada ternak unggas. Tujuan penelitian untuk mengetahui aktivitas antimikroba dan antioksidan dari ekstrak tepung daun dan buah mengkudu. Metode yang digunakan adalah metode percobaan untuk menetukan aktivitas antimikroba dan antioksidan dari ekstrak metanol tepung buah mengkudu, tepung daun mengkudu dan kombinasi tepung buah-daun mengkudu. Uji daya hambat mikroba dengan metode sumuran (difusi agar), uji kandungan total fenol dengan metode Folin-Ciocalteu, uji Flavonoid dengan motode Aluminium clorida dan uji antioksidan dengan metode DPPH (1,1-Diphenyl-2picrylhydrazyl). Hasil penelitian menunjukkan bahwa ekstrak tepung mengkudu memberikan pengaruh yang sangat nyata $(\mathrm{P}<0,01)$ terhadap daya hambat BAL dan Escherichia coli. Kandungan total fenol yang tertinggi terdapat pada tepung buah yaitu sebesar $1,67 \mathrm{mg} / \mathrm{g}$ GAE. Kandungan flavonoid yang tertinggi terdapat pada tepung daun yaitu sebesar $0,0438 \mathrm{mg} / \mathrm{g}$ QE. Hasil uji DPPH yang tertinggi terdapat pada tepung buah yaitu sebesar $84,03 \%$. Ekstrak tepung buah mengkudu mempunyai potensi sebagai antioksidan dan antimikroba pada ternak.
\end{abstract}

Kata kunci: Buah mengkudu, Total fenol, Flavonoid, Uji DPPH, Daya hambat mikroba

ABSTRACT: Noni fruit is a medical plant with active compound like antimicrobial and antioxidant that could potentially be used as a feed additive in poultry. This study aimed to determine the activity antimicrobial and antioxidant of noni fuit leave and fruit extract. The method was field experiment arranged in Completely Randomize Design with 3 treatments and 3 replications. The treatments are metanol extract of noni fruit powder, leave noni powder and combination noni fruit and leave powder. The inhibition zone diameter was determined by disc diffusion method, total phenol was determined by Folin-Ciocalteu method, Flavonoid was determined by Aluminium clorida method and antioxidant activity by DPPH (1,1-Diphenyl-2picrylhydrazyl) method. The results showed that noni powder extract had significantly effect $(\mathrm{P}<0.01)$ in inhibition of Lactic Acid Bacteria and Escherichia coli. The total phenol of Noni fruit powder is highest approximately $1.67 \mathrm{mg} / \mathrm{g}$ GAE. The flavonoid of Noni leave is highest approximately $0.0438 \mathrm{mg} / \mathrm{g}$ QE. The DPPH test of Noni fruit is highest approximately $84.03 \%$. It can be concluded that noni fruit extract can be used as an antibacterial and antioxidant in poultry.

Keywords: Noni fruit, Total phenol, DPPH test, Inhibition zone diameter.

*Corresponding Author: davidkurniawan@kahuripan.student.ac.id 


\section{PENDAHULUAN}

Penggunaan antibiotik sebagai feed additivemulai ditinggalkan karena menimbulkan residu antibiotik di dalam produk ternak yangmenyebabkan alergi, mengganggu keseimbangan mikroorganisme di saluran pencernaan dan resistensi terhadap antibiotik. Mengkudu atau Noni (Morinda citrifolia L. (Rubiaceae)) merupakan salah satu tanaman obat yang mempunyai senyawa bioaktif antioksidan dan antimikroba sebagai alternatif penggunaan antibiotik pada ternak unggas. Blanco et al. (2006) melaporkan bahwa lebih dari 160 komponen fitokimia telah diidentifikasi dari tanaman Noni dan sebagian besar adalah senyawa fenol, asam organik dan alkanoid. Senyawa fenol yang telah dilaporkan meliputi anthraquinones (damnacanthal, morindone, morindin dll), aucubin, asperuloside dan scopoletin. Senyawa asam organik utama meliputi asam kaproat dan asam kaprilat. Singh (2012) melaporkan bahwa mengkudu mempunyai aktivitas bioaktif seperti antibakteri, antiviral, antihelmintic antifungal, antioksidan, hepatoprotektive, antiobesity, hypoglycaemic, analgesic, anxiolytic, anti-imflamatory, hypotensive, cardiovascular activity, estrogenic, immunological dan anticancer. Berdasarkan uraian diatas perlu adanya penelitian tentang penggunaan tepung mengkudu sebagai feed additive terhadap aktivitas antimikroba dalam uji daya hambat mikroba dan aktivitas antioksidan yang dilihat dari uji total fenol, kadar flavonoid dan uji $D P P H$.

\section{MATERI DAN METODE}

Penelitian bertujuan mengetahui aktivitas antimikroba dalam uji daya hambat mikroba dengan menggunakan isolat Bakteri Asam Laktat dan Escherichia coli dan analisa kandungan antioksidan terbaik (kandungan total fenol, flavonoid dan uji DPPH) dari tanaman mengkudu (tepung buah, tepung daun dan tepung buah-daun) sebagai feed additive pada skala laboratorium. Bagian tanaman yang digunakan dalam penelitian ini adalah daun dan buah mengkudu. Daun mengkudu diperoleh dari tanaman mengkudu yang belum berbuah.
Buah mengkudu yang digunakan adalah buah mengkudu yang telah matang.

Bahan yang digunakan pada penelitian ini adalah aquades, antibiotic (tetrasiklin), ekstrak metanol tepung mengkudu, media uji MRS-A dan media uji EMBA, reagen Folin-Ciocalteau, $\mathrm{Na}_{2} \mathrm{CO}_{3}$, aluminimum trichloride $\left(\mathrm{AlCl}_{3}\right), \mathrm{NaNO}_{2}, \mathrm{NaOH}$, Asam Galat, Quersetin, Metanol dan Larutan DPPH. Preparat mikrobiologi yang digunakan adalah isolat BAL dan isolat Escherechia coli yang diperoleh dari Laboratorium Uji Jurusan Teknologi Hasil Pertanian Fakultas Teknologi Pertanian, Universitas Brawijaya Malang. Peralatan yang digunakan pada adalah cawan petri, tabung reaksi, erlenmeyer, incubator, timbangan ohaus, mikropipet $1 \mathrm{~mL}$, autoklaf, waterbath dan magnetic stirrer, beaker glass, erlenmeyer, centrifus, rotary evaporator, Nylon filter dan spektrofotometer.

\section{Ekstrak tanaman mengkudu}

Buah dan daun mengkudu dicuci bersih menggunakan air mengalir. Dipotong melintang setebal $1 \mathrm{~cm}$ dan dikeringkan menggunakan oven $45{ }^{\circ} \mathrm{C}$ selama 2-3 hari. Buah dan daun yang telah kering digiling sampai halus dan dilakukan pengayakan dengan ukuran 75 mesh $(0,75 \mathrm{~mm})$. Metode ekstraksi tepung mengkudu adalah meserasi menggunakan pelarut metanol berdasarkan metode ekstraksi metanol (Zin et al., 2002) yang dimodifikasi. Tahap ekstraksi dilakukan dengan mencampurkan tepung buah atau tepung daun dengan pelarut metanol dengan perbandingan 1:4. Hasil campuran diendapkan selama satu malam. Selanjutnya dihomogenkan menggunakan waterbath shaker dengan kecepatan $180 \mathrm{rpm}$ selama 60 menit pada suhu ruang. Larutan disaring dan diperoleh larutan ekstrak metanol 1 kemudian residu (ampas) dikeringkan pada suhu ruang dan dilakukan maserasi kembali hingga diperoleh ekstrak metanol 2. Hasil ekstraksi metanol 1 dan 2 dilakukan pencampuran. Kemudian dilakukan tahap evaporasi pada suhu $70{ }^{\circ} \mathrm{C}$ untuk memisahkan hasil ekstrak yang didapat dengan pelarut metanol. Hasil ekstrak disimpan di 
dalam refrigerator suhu $5-10{ }^{\circ} \mathrm{C}$ untuk pengawetan.

\section{Uji daya hambat mikroba}

Metode yang digunakan adalah percobaan laboratorium untuk melihat daya hambat mikroba dengan menggunakan metode sumuran (difusi agar) modifikasi dari Purwantiningsih dkk. (2014) untuk mengetahui aktivitas ekstrak tanaman mengkudu dengan variasi ekstrak tepung buah, ekstrak tepung daun dan kombinasi (1:1) serta konsentrasi 50 \%, 37,5\%, $25 \%$ dan $12,5 \%$ ekstrak terhadap pertumbuhan bakteri BAL dan Escherichia coli sehingga diperoleh daerah hambatan di sekeliling sumuran.

\section{Uji kandungan total fenol, flavonoid dan uji DPPH}

Metode yang digunakan adalah percobaan laboratorium untuk membandingkan kandungan total fenol, flavonoid dan uji DPPH dari ekstrak tanaman mengkudu dengan variasi ekstrak tepung buah, ekstrak tepung daun dan campuran ekstrak tepung buah dan daun. Kandungan total fenol ekstrak tepung mengkudu ditentukan dengan metode Folin-Ciocalteu dan penentuan kadar total fenol berdasarkan equivalen asam galat modifikasi metode Kaur and Mondal (2014). Sebanyak $1 \mathrm{~mL}$ sampel ekstrak ditambahkan $1 \mathrm{~mL}$ reagen FolinCiocalteu (50\%) dan campuran ini divortex selama 3 menit. Kemudian ditambahkan 1 mL larutan $\mathrm{Na}_{2} \mathrm{CO}_{3} 2 \%$ dan disimpan dalam ruang gelap selama 30 menit. Absorbansi ekstrak diukur pada panjang gelombang $750 \mathrm{~nm}$ dengan spektrofotometer. Hasil absorbansi dinyatakan dengan ekuivalen asam galat dalam $\mathrm{mg} / \mathrm{g}$ ekstrak. Kadar total flavonoid ekstrak tepung mengkudu ditentukan dengan metode Aluminium klorida dan penentuan kadar flavonoid berdasarkan equivalen quersetin modifikasi metode Kumar et al. (2008). Sampel ekstrak sebanyak $1 \mathrm{~mL}$ sampel dimasukkan dalam labu takar $10 \mathrm{~mL}$ yang berisi $4 \mathrm{~mL}$ akuades dan ditambahkan 0,3 mL larutan $\mathrm{NaNO}_{2} 5 \%(\mathrm{~b} / \mathrm{v})$. Sesudah 5 menit ditambahkan $0,3 \mathrm{~mL}$ larutan $\mathrm{AlCl}_{3}$ $10 \%(\mathrm{~b} / \mathrm{v})$, lalu sesudah 6 menit ditambahkan $2 \mathrm{~mL}$ larutan $1 \mathrm{~mol} / \mathrm{L} \mathrm{NaOH}$ dan diencerkan hingga volume $10 \mathrm{~mL}$ dengan akuades. Absorbansi larutan diukur pada $\lambda 510 \mathrm{~nm}$. Kadar flavonoid total dinyatakan ekuivalen kuersetin (QE). Aktivitas antioksida ditentukan dengan metode uji aktivitas penangkalan DPPH (1,1-Diphenyl-2 picrylhydrazyl) berdasarkan efektivitas penangkalan ekstrak tanaman mengkudu terhadap DPPH modifikasi metode Kaur and Mondal (2014). Larutan ekstraksebanyak $0,1 \mathrm{~mL}$ ditambahkan 2 mL larutan DPPH 0,02 mol dibiarkan di tempat gelap pada suhu kamar selama 30 menit. Penurunan absorbansi DPPH diukur pada panjang gelombang $515 \mathrm{~nm}$ dengan spektrofotometer. Larutan kontrol digunakan campuran $0,1 \mathrm{~mL}$ metanol dan 2 mL larutan DPPH 0,02 mol.

\section{Analisa data}

Data penelitian ditabulasi pada excel dan dianalisa dengan Rancangan Acak Lengkap (RAL), dan dilanjutkanUji Jarak Berganda Duncan's apabila terdapat perbedaan pengaruh yang nyata atau sangat nyata.

\section{HASIL DAN PEMBAHASAN \\ Senyawa aktif antioksidan tepung mengkudu.}

Hasil penelitian pengaruh penggunaan tepung mengkudu dengan metode ekstraksi metanol terhadap kandungan antioksidan ditampilkan pada Tabel 1. Data kandungan senyawa antioksidan tepung mengkudu menunjukkan bahwa pada jenis tepung mengkudu dengan metode ekstraksi metanol memberikan pengaruh yang berbeda sangat nyata $(\mathrm{P}<0,01)$ terhadap kandungan total fenol. Kandungan total fenol berurutan dari yang tertinggi terdapat pada tepung buah, tepung buah-daun dan tepung daun yaitu sebesar 1,67, 1,32 dan 1,09 $\mathrm{mg} / \mathrm{g}$ GAE. 
Tabel 1. Kandungan senyawa antioksidan tepung mengkudu dengan metode ekstraksi metanol.

\begin{tabular}{lccc}
\hline \multirow{2}{*}{ Variabel } & \multicolumn{3}{c}{ Perlakuan } \\
\cline { 2 - 4 } & Tepung Buah & Tepung Daun & Tepung Buah-Daun $(1: 1)$ \\
\hline Total Fenol (mg/g GAE) & $1,670 \pm 0,102^{\mathrm{a}}$ & $1,095 \pm 0,241^{\mathrm{b}}$ & $1,327 \pm 0,120^{\mathrm{a}}$ \\
Flavonoid (mg/g $E Q)$ & $0,0017 \pm 0,0001^{\mathrm{a}}$ & $0,0438 \pm 0,0013^{\mathrm{c}}$ & $0,0137 \pm 0,0021^{\mathrm{b}}$ \\
Penangkalan DPPH $(\%)$ & $84,03 \pm 1,60^{\mathrm{a}}$ & $37,54 \pm 8,51^{\mathrm{c}}$ & $54,34 \pm 3,70^{\mathrm{b}}$ \\
\hline
\end{tabular}

Keterangan: notasi yang berbeda menunjukkan perbedaan yang sangat nyata $(\mathrm{P}<0,01)$

Kandungan total fenol tertinggi terdapat pada tepung buah mengkudu. Perbedaan kandungan total fenol antara tepung buah dan tepung daun mengkudu merupakan hal yang mungkin terjadi karena pada dasarnya komposisi senyawa bioaktif yang ada pada keduanya berbeda. Krishnaiah, et al. (2012) melaporkan hasil yang berbeda bahwa kandungan total fenol dari daun, buah dan akar mengkudu secara berurutan yaitu sebesar 9,06, 8,73 dan 14,88 $\mathrm{mg} / \mathrm{g}$. Assanga, et al. (2013) melaporkan bahwa kandungan total fenol buah mengkudu dengan variasi tingkat kematangan dan musim panen berkisar antara 1,426 sampai 3,647 mg/g GAE. Kandungan total fenol berubah secara tidak beraturan, selama Mei sampai Juni dengan kondisi iklim yang panas mengalami peningkatan dan pada tingkat kematangan stage 2 (middle) mengalami peningkatan, kemudian mengalami penurunan pada stage 3 (sub-mature) dan kembali mengalami peningkatan pada stage 4 (mature). Yang, et al. (2011) melaporkan bahwa kandungan total fenol buah mengkudu mengkal (sub-mature) sebesar 2,848 mg/g GAE lebih besar 1,3 kali lipat dibandingkan dengan buah yang matang sebesar 2,253 mg/g GAE.

Data kandungan senyawa antioksidan tepung mengkudu menunjukkan bahwa pada tepung mengkudu dengan metode ekstraksi metanol menunjukkan pengaruh yang berbeda sangat nyata $(\mathrm{P}<0,01)$ terhadap kandungan flavonoid. Kandungan flavonoid pada penelitian ini berurutan dari yang tertinggi terdapat pada tepung daun, tepung buah-daun dan tepung buah yaitu sebesar 0,0438, 0,0137 dan 0,0017 mg/g QE. Kandungan flavonoid tertinggi terdapat pada tepung daun. Senyawa bioaktif yang ada pada bagian daun dan buah mengkudu atau tanaman pada umumnya dapat dipastikan berbeda karena masingmasing bagian tumbuhan mempunyai fungsi fisiologis yang berbeda. Senyawa bioaktif yang telah diindentifikasi dan diisolasi dari tanaman mengkudu telah dihimpun oleh Assi et al. (2015) menunjukkan bahwa pada bagian daun senyawa yang banyak ditemukan meliputi asam amino, flavonoid, triterpenoid, sterol, iridoid, kaempferol, scopoletin. Senyawa bioaktif bagian buah mengkudu terdiri dari asam organik, asam lemak, vitamin, iridoid, flavonoid dan antraquinon. Deng, et al. (2010) menyatakan bahwa tanaman mengkudu yang tumbuh dibelahan dunia menunjukkan variasi jenis dan jumlah komposisi senyawa fitokimia. Variasi senyawa fitokimia berhubungan dengan perbedaan kondisi lingkungan selama pertumbuhan (temperature, pencahayaan dan tanah), tingkat kematangan dan aktivitas selama panen dan pasca panen (umur panen, pematangan, pemanenan, penyimpanan, transportasi dan prosesing).

Data kandungan senyawa antioksidan tepung mengkudu menunjukkan bahwa pada tepung mengkudu dengan metode ekstraksi metanol memberikan pengaruh yang berbeda sangat nyata $(\mathrm{P}<0,01)$ terhadap aktivitas antioksidan. Hasil uji DPPH pada penelitian ini berurutan dari yang tertinggi terdapat pada tepung buah, tepung buah-daun dan tepung daun yaitu sebesar 84,03, 54,34 dan 37,54\%. Aktivitas penangkalan radikal bebas DPPH tertinggi terdapat pada tepung buah. Kumar, et al. (2004) melaporkan bahwa aktivitas penangkalan radikal bebas DPPH dari berbagai ekstrak buah mengkudu menunjukkan bahwa ekstrak etil asetat $(49,78 \%)$, aquadest $(52,11 \%)$ dan etanol $(53,50 \%)$ 
lebih rendah dibandingkan dengan larutan standar ascorbic acid $(81,19 \%)$ dan BHT (72,67\%). Zin, et al. (2002) melaporkan bahwa aktivitas antioksidan dari akar, buah dan daun mengkudu dengan menggunakan metode Ferric Thiocyanate (FTC) menunjukan bahwa ekstrak metanol akar mengkudu mempunyai aktivitas antioksidan lebih tinggi daripada buah dan daun. Aktivitas antioksidan dengan ekstrak etil asetat pada semua bagian mengkudu mempunyai aktivitas yang lebih tinggi dibandingkan dengan $\alpha$-tocopherol dan $\mathrm{Bu}$ tylated Hydroxytoluene (BHT).

\section{Daya hambat mikroba tepung mengku- du.}

Hasil penelitian menunjukkan bahwa penggunaan jenis tepung mengkudu dengan ekstrak metanol menunjukkan pengaruh yang sangat nyata $(\mathrm{P}<0,01)$ terhadap daya hambat BAL dan Escherichia colidibandingkan dengan kontrol negatif. Daya hambat mikroba dari ketiga jenis tepung mengkudu tidak menunjukkan pegaruh yang berbeda nyata pada Escherichia coli maupun BAL. Daya hambat mikroba dari tepung mengkudu menunjukkan penghambatan lebih besar pada Escherichia coli dibandingkan dengan BAL. Senyawa antimikroba pada tepung mengkudu mampu menghambat pertumbuhan bakteri gram negatif (Escherichia coli) sedangkan penghambatan pada bakteri gram positif (BAL) relatif lemah. Perbedaan daya hambat ini disebabkan oleh perbedaan dinding sel bakteri. Pelezar dan Chan (1988) menyatakan bahwa perbedaan ketebalan dinding sel bakteri gram positif dan bakteri gram negatif menghasilkan reaksi yang berbeda terhadap senyawa fenolik. Potensi aktivitas antimikroba tepung mengkudu diindikasi disebabkan karena terdapat senyawa fenol dan flavonoid. Oliver, et al. (2001) menyatakan bahwa senyawa fenol telah dilaporkan mempunyai aktivitas antibakteri terhadap bakteri gram positif dan gram negatif. Senyawa fenol dalam konsentrasi yang tinggi mampu merusak dinding sel bakteri dan dalam konsentrasi yang rendah fenol dapat mengganggu kerja sistem enzim penting dalam sel bakteri.

Tabel 2. Daya hambat mikroba tepung mengkudu dengan metode ekstraksi metanol (mm).

\begin{tabular}{lcc}
\hline \multicolumn{1}{c}{ Perlakuan } & Escherichia coli & Bakteri Asam Laktat \\
\hline Kontrol Negatif & $0 \pm 0,00^{\mathrm{a}}$ & $0 \pm 0,00^{\mathrm{a}}$ \\
Tepung Buah & $7,92 \pm 1,44^{\mathrm{b}}$ & $5,6 \pm 0,81^{\mathrm{b}}$ \\
Tepung Daun & $7,27 \pm 2,03^{\mathrm{b}}$ & $4,6 \pm 2,91^{\mathrm{b}}$ \\
Tepung Buah-Daun & $8,47 \pm 1,97^{\mathrm{b}}$ & $8,0 \pm 2,26^{\mathrm{b}}$ \\
Antibiotik (Tetrasiklin) & $21,2 \pm 1,15^{\mathrm{c}}$ & $16,4 \pm 1,47^{\mathrm{c}}$ \\
\hline
\end{tabular}

Keterangan: notasi yang berbeda pada kolom yang sama menunjukkan perbedaan yang sangat nyata $(\mathrm{P}<0,01)$

Damayanti dan Suparjana (2007) menjelaskan mekanisme fenol dalam menghambat mikroba adalah kerusakan membran sel, menginaktifkan enzim dan mendenaturasi protein sehingga mengalami penurunan permeabilitas. Perubahan permeabilitas akan menganggu transportasi ion-ion organik ke dalam sel yang berakibat pada terhambatnya pertumbuhan mikroba atau bahkan kematian mikroba. Senyawa flavonoid merupakan senyawa yang mempunyai aktivitas antibakteri dengan menganggu fungsi dinding sel sehingga terjadi lisis pada sel bakteri. Flavonoid memiliki penghambatan yang besar pada bakteri gram positif dari pada bakteri gram negatif karena bersifat polar sehingga menembus lapisan peptidolikan yang bersifat polar daripada lapisan lipid yang bersifat non-polar (Pangestuti, Sumardianto, dan Amalia, 2017). Perlakuan antara jenis tepung tanaman mengkudu (tepung buah, tepung daun dan tepung buah-daun) menunjukkan pengaruh yang tidak nyata $(\mathrm{P}>0,05)$ terhadap diameter daya hambat BAL dan Escherichia coli. Zona hambat pada tepung tanaman mengkudu masih lebih rendah dibandingkan dengan zona hambat yang dihasilkan oleh antibiotik komersial. Perlakuan kontrol aquades 
menunjukkan tidak terdapat zona hambat, karena tidak adanya komponen bioaktif yang berfungsi sebagai antimikroba sehingga tidak ada aktivitas penghambatan terhadap pertumbuhan mikroba.

\section{KESIMPULAN DAN SARAN}

Tepung mengkudu mempunyai aktivitas antimikroba dan antioksidan yang tertinggi. Penggunaan tepung mengkudu sebagai aditif pakan dapat menjadi alternatif penggunaan antibiotik pada ternak unggas.

\section{DAFTAR PUSTAKA}

Assanga S.B.I., Lewis L.L.M., Rivera C.E.G. Gil-Salido, A.A. Acosta-Silva A.L., Meza-Cueto C.Y. and RubioPino J.L. 2013. Effect of Maturity and Harvest Season on Antioxidant Activity, Phenolic Compounds and Ascorbic Acid of Morinda citrifolia L. (noni) Grown in Mexico. African Journal of Biotechnology, 12(29), 4630-4639.

Assi, R.A., Y. Darwis, Ibrahim M.A., Arshad A.K, L. Vuanghao and M.H. Laghari. 2015. Morinda citrifolia (Noni): A Comprehensive Review on Its Industrial Uses, Pharmacological Activities, and Clinical Trials. Arabian Journal of Chemistry, 10(5),: 691707.

Blanco Y.C., F. Vaillant, A.M. Perez, M Reynes, J.M. Brillouet and P. Brat. 2006. The Noni Fruit: A Review of Agriculture Research, Nutritional and Teurapeutic Properties. Journal of Food Composition and Analysis, 19(6-7), 645-654.

Damayanti, E. dan T.B. Suparjana. 2007. Efek Penghambatan Beberapa Fraksi Ekstrak Buah Mengkudu terhadap Shingella dysenteriae. Prosiding Seminar Nasional Teknik Kimia Kejuangan. Fakultas Biologi Universitas Jendral Soedirman. Yogyakarta.
Deng, S., West B.J., and Jensen C.J. 2010. A Quantitative Comparison of Phytochemical Components in Global Noni Fruits and Their Commercial Products. Food Chemistry, 122(1), 267270.

Kaur S. and P. Mondal. 2014. Study of Total Phenol and Flavonoid Content, Antioxidant Activity and Antimicrobial Properties of Medicinal Plants. Journal of Microbiology and Experimentation 1(1): 00005

Krishnaiah, D., Nithyanandam, R., \& Sarbatly, R. 2012. Phytochemical Constituents and Activities of Morinda citrifolia L. Dalam V. Rao (Ed.), Phytochemicals. Rijeka: Intech Open. https://doi.org/10.5772/26094

Kumar, S.N.K., M. Suresh, S.A. Kumar and P. Kalaiselvi. 2014. Bioactive Compounds, Radical Scavering, Antioxidant Properties and FTIR Spectroscopy Study of Morinda clitrifolia Fruit Extracts. International Journal of Current Microbiology and Applied Sciences, 3(2), 28-42.

Zin, Z. M., Abdul-Hamid, A., \& Osman, A. (2002). Antioxidative activity of extracts from Mengkudu (Morinda citrifolia L.) root, fruit and leaf. Food Chemistry, 78(2), 227-231.

Oliver, S.P., B.E. Gillespie, M.J. Lewis, S.J. Ivey, R.A. Almeida, D.A. Moorrehead and H.H. Dowlen. 2001. Efficiency of a New Premilking, Teat Disinfectant Containing a Phenolic Combination for The Prevention of Mastitis. Journal Diary Science, 84, 1545-1549.

Pelezar M.J. dan E.C.S. Chan. 1988. Dasar-Dasar Mikrobiologi. Terjemahan. Universitas Indonesia Press. Jakarta.

Purwantiningsih, Suranindyah dan Widodo. 2014. Aktivitas Senyawa Fenol dalam Buah Mengkudu (Morinda cit- 
rifolia) sebagai Antibakteri Alami untuk Penghambatan Bakteri Penyebab Mastitis. Buletin Peternakan, 38(1), 59-64.

Pangestuti, I. E., Sumardianto, dan Amalia, U. 2017. Skrining Senyawa Fitokimia Rumput Laut Sargassum Sp. dan Aktivitasnya Sebagai Antibakteri Terhadap Staphylococcus aureus dan Eschericia coli. Ijfst, 12(2), 98-102.

Singh, D.R. 2012. Morinda citrifolia L: A Review of the Scientific Validation for Its Nutritional and Therapeutic Properties. Journal of Diabetes and Endocrinology, 3(6), 77-91. 